\title{
THE JUDGES AND THE EXECUTIVE - HAVE THE GOALPOSTS BEEN MOVED?
}

\section{DENNING LECTURE 2005*}

\author{
Lord Lloyd of Berwick ${ }^{* *}$
}

In lectures named after famous men, it is the custom for the lecturer to start with a tribute to the great man in question. This is as it should be. In the case of Lord Denning, the greatest judge of our time, one could start easily enough. The difficulty would be knowing where to stop. Fortunately the task of doing justice to Lord Denning, both as a person and as a judge, was undertaken by Lord Bingham before a huge congregation in Westminster Abbey in June 1999. It will never be done better. So instead I will refer to just three incidents in his life.

The first was at a lecture which he gave in Cambridge in 1950, shortly after his judgment in Central London Properties v High Trees House. ${ }^{1}$ The title of the lecture was "The Need for a New Equity." At the end of the lecture an undergraduate at the back of the hall asked, "Where is this new equity going to come from?" "Modesty" said Lord Denning in that marvellous Hampshire burr, "forbids me to say."

The second incident was towards the end of his career when he was much given to writing books. He gave me a copy of one in which he wrote:

"To Tony Lloyd, the most accomplished of Judges, confident that he will soon reach the Court of Appeal.... and to Jane who charms us all...”

You can imagine my pride and delight. So I took it next door to show to my friend Christopher Staughton. "Ah" he said as he went to a shelf, and took down another copy of the same book. In it I read:

"To Christopher Staughton, the most accomplished of Judges....and to Joanna who charms us all..."

You can see why so many people regarded him as not only the greatest judge of our time, but also the most endearing.

\footnotetext{
* Delivered to The Denning Society Lincoln’s Inn Hall, 23 November 2005.

** Rt Hon Lord Lloyd of Berwick, a former Lord of Appeal in Ordinary.

${ }^{1}$ Central London Properties v High Trees House [1947] KB 130.

${ }^{2}$ Lord Denning “The Need for a New Equity” (1952) 5 Current Legal Problems 1.
} 


\section{THE DENNING LAW JOURNAL}

Finally, something from the end of his life. It is a letter written by Sir Edward Ford to The Queen describing the occasion on which he presented Lord Denning with the badge of the Order of Merit. I have Sir Edward's permission to quote from the letter, and I wish that I had time to quote it all. Sir Edward describes the house in Whitchurch, only a stones throw from Lord Denning's birthplace in a drapers shop in the middle of the town. Lord Denning was sitting in his library, immobile, looking into space rather like a statue of The Buddha. He had insisted on dressing up for the occasion and was wearing a morning coat, grey waistcoat and black striped trousers. After the badge had been presented, and the ribbon placed round his neck, Lord Denning spoke "with considerable humour and discernment about his colleagues." $\mathrm{He}$ talked also "with relish of his enjoyment of presiding in the Court of Appeal as Master of the Rolls, where he could exercise his own judgment as to the intention of an Act of Parliament, as opposed to those who felt that this was no business of a Court of Law." He admitted that he was sometimes wrong, and not infrequently reversed on appeal. He constantly referred to the love of his garden, straddling the Test, which according to him, "was the most beautiful garden in England." That is the picture which Sir Edward Ford paints of a great and good man in extreme old age. It reminds one of the death of Falstaff: "His nose was as sharp as a pen and he babbled of green fields."

I now turn with reluctance to the subject of my lecture. I will start with a quotation. It comes from a debate initiated by Lord Irvine of Lairg in the House of Lords to call attention to the relations between the judiciary, the legislature and the executive.

"I believe that this debate is timely. It comes when the country must believe that there is unprecedented antagonism between the judges and the Government both over Judicial Review of ministerial decisions and the restrictions which the Government propose on the judicial discretion in sentencing. Certainly, there has been a long string of decisions striking down Ministerial actions as unlawful. That has even led to some politicians calling Judicial Review itself into question. The public must be perplexed by what they perceive as a major clash over the distinct roles of Parliament, Ministers and the judges.”

That debate could have taken place at any time during the last few years. It in fact took place during the dying days of the Conservative Government in June 1996, when Michael Howard was Home Secretary. The politicians to whom Lord Irvine referred as having called Judicial Review into question, were not, of course, Labour politicians but Conservative politicians. 


\section{THE DENNING LAW JOURNAL}

I start with that quotation because I want to emphasise at the outset, that I shall not be attacking the attitude of any particular Government. Indeed I shall not be attacking anyone at all. The title of my lecture is not "Judges and the Government," which might have been understood as a reference to this Government; but judges and the executive. My theme will be that so far as relations between judges and the executive are concerned, all Governments are much the same. One might have thought that a Labour Government would be less executive-minded (to use Lord Aitkins' famous phrase) and less authoritarian than a Conservative Government. But this has not proved to be the case.

So if I refer to events when Mr Blunkett was Home Secretary, and now Mr Clarke, that is only because they are more recent, and therefore fresher in our minds. If a week in politics is a long time, the days when Mr Howard was Home Secretary, although only ten years ago by the calendar, seem like the Middle Ages.

In his recent press conference the Lord Chief Justice said that there is no conflict between the judges and the Government. He was right. However the fact that there is no conflict, does not mean there is not tension. There is, and always will be. For if there is no tension between the judges and the executive, it will mean that the judges are not doing their proper job. Yet it would be an error to think that the tension is greater now than it ever was. When $\mathrm{Mr}$ Blunkett wrote in the Evening Standard that confidence in our criminal justice system was at an all time low, the late Earl Russell pointed out that he was mistaken. In 1388, all the judges were impeached, and the Chief Justice was executed. In 1609 when James I was arguing with his Chief Justice Sir Edward Coke, the King became so incensed that he threw a punch. Things are not as bad as that.

Lord Irvine in his speech referred to two of the main areas of tension, Judicial Review and sentencing. I shall look at each of those in turn. There are, of course, other areas of underlying tension. But these are the areas where the tension most frequently comes to the surface.

I start with Judicial Review, because Judicial Review is so little understood by the public and is so often misepresented by the press. What is Judicial Review? It is the means by which judges exercise control over administrative acts, including acts of the executive. The purpose of Judicial Review, put very simply, is to make sure that the executive acts within the law, and in particular within the powers they have been given by Parliament. The extent of those powers is a question of law; and it is the existence of that question of law which justifies the intervention of the courts. Once Parliament has granted the powers, whatever they may be, it is not for Parliament to say what they mean, and still less the executive. It is for the courts. 


\section{THE DENNING LAW JOURNAL}

Every other western country has a system of administrative law, in many cases more advanced than our own. Thus in most if not all western countries there is a right to challenge legislation, both before and after it has been made. Such a right would be unthinkable under our system. Nevertheless, the right of the courts to question the lawfulness of administrative acts has always been there, even though it was exercised sparingly, and on more limited grounds, under the guise of the old prerogative writs. In the great case of Conway $v$ Rimmer $^{3}$ in 1968 Judicial Review was given a second birth. In 1976 it was given a new name. It was the rebirth and subsequent growth of judicial review which Lord Diplock described as the most important event in his judicial career.

In 1976 there were some 500 applications for Judicial Review. By 2000 there were 4,242. By 2004 it had reached 6,057. This year it is likely to exceed 10,000 . Ministers use these figures to suggest that the judges are becoming too aggressive. Are they right? Is there any evidence that the judges have been stepping beyond their constitutional role? Are they exercising a political function in Judicial Review or are they not? Those are the very questions which Lord Wilberforce posed in the debate in the House of Lords in 1996 to which I have already referred. In 1996 he answered both questions with a categoric negative. I believe he would give the same answers today.

So what is the explanation for this great increase in Judicial Review? Well the first and obvious point is that the courts have no control over the number of applications that are made. Anybody can apply for Judicial Review, if he has a grievance or feels he has a grievance, because of some action or inaction on the part of the executive. The judges cannot stop him. So the relevant question is not how many applications are made, but how many applications have succeeded. In fact the number of successful applications has fallen steadily from 730 in 2000 to 141 in 2004, and the proportion of successful applications has remained roughly the same, at a little over half.

So what is the explanation for the huge increase in the number of applications for Judicial Review, since it clearly cannot be that the judges are becoming more aggressive. One obvious explanation is the increase in the number of asylum seekers. Another is that as we become subject to more and more regulation in our everyday lives there is more and more scope for genuine grievances. Moreover we are now more than ever aware from what we read in the newspapers of our right to ventilate those grievances in court. Those reasons are surely enough to explain the increase.

I accept, of course, that if the substantive grounds for quashing a decision of the executive had become more favourable to the complainant, then the executive might indeed have cause for concern. But I see no evidence that that

${ }^{3}$ Conway v Rimmer and Another [1968] AC 910. 


\section{THE DENNING LAW JOURNAL}

is so. It is true that, the language in which the test is expressed has moved on from the original statement in Wednesbury ${ }^{4}$ through the more recent formulation of Lord Diplock in the $G C H Q^{5}$ case. But the underlying function of the judge in Judicial Review is exactly the same as it always was; he is not to substitute his own views of what is reasonable for that of the executive. He is there to ensure that the executive comply with the rule of law. Judicial Review is thus the foundation of the rule of law, just as habeas corpus is the foundation of personal liberty. Unless the judges perform that vital function, the outlook for our Parliamentary democracy would be bleak indeed.

So if I am right that the answers to Lord Wilberforce's questions are the same now as they were in 1996; if, in other words, the judges are not exercising a political function in Judicial Review, or straying beyond their constitutional role, the next question is whether there have been any departures from that general rule. Can the executive point to any case in which an individual judge has gone beyond his proper role? This is what Mr Blunkett set out to do in 2003. The judge in question was Mr Justice Collins.

The case was an application for Judicial Review arising out of the Nationality, Immigration and Asylum Act 2002. That was the Act under which asylum seekers were required to lodge their claims for asylum as soon as reasonably practicable after arrival, or lose their right to benefits. It is important to notice that the judge did not say that the legislation was incompatible with the Human Rights Act or anything of that sort. He said merely that the way in which immigration officials were operating the Act was unfair. He said also that depriving asylum seekers of all means of support could amount to inhuman or degrading treatment in breach of Article 3 of ECHR, a point on which he was upheld very recently by the House of Lords: see Limbuela $v$ Secretary of State for Home Affairs. ${ }^{6}$ Mr Justice Collins delivered his judgment in the usual way at 10.30am on 19 February 2003 in the Administrative Court in the Royal Courts of Justice. Mr Blunkett was interviewed the next day on the BBC Radio 4 programme "World at One." $\mathrm{He}$ said:

"Frankly, I am fed up with having to deal with a situation where Parliament debates the issues and the judges then overturn them...I am absolutely clear that we do not accept what Mr Justice Collins has said. We will seek to overturn it.”

\footnotetext{
${ }^{4}$ Associated Provincial Picture Houses Ltd v Wednesbury Corpn [1948] 1 KB 223.

${ }^{5}$ Council of Civil Service Unions and others $v$ Minister for the Civil Service [1985] 1 AC 374.

${ }^{6} R$ (Limbuela) $v$ Secretary of State for the Home Department; $R$ (Tesema) $v$ Same; $R$ (Adam) v Same [2005] UKHL 66, [2006] 1 AC 396.
} 


\section{THE DENNING LAW JOURNAL}

In fact the relevant provisions of the 2002 Act were debated very little. They were introduced by a late Government amendment in the House of Lords. But I pass that by. I will come back later to the way in which Mr Blunkett attempted, as he put it, "to deal with the situation." At this stage I note only that these words were not spoken in the heat of the moment. They were spoken the following day after time for reflection.

In due course the Home Office did indeed seek to overturn Mr Justice Collins' decision. But they failed. On 18 March the Court of Appeal dismissed the appeal, holding that the system established under the Act for restricting benefits "had serious defects," and had, as Mr Justice Collins had said, been applied unfairly.

It would have been well if the matter had ended there. But it did not. After still further time for reflection, Mr Blunkett wrote an article for the Evening Standard. The headline was: "I won't give in to the judges." 7 He called for a long hard look at the constitutional relationship between Parliament and the judges, and was clear as to how that relationship had changed.

"Judges now routinely use Judicial Review to rewrite the effect of the law that Parliament has passed.”

The article concludes:

"At the moment we all too often have the worst of all worlds in which Parliament deliberates for months over laws which are then systematically undermined by overly aggressive Judicial Review decisions.”

A few days later he addressed the Police Federation at Blackpool. He denied rumours that he was:

"not at all pleased with the judges, I just want judges to live in the same real world as the rest of us; I just like judges who help us and help you to do the job.”

The rumour that Mr Blunkett was not at all pleased with the judges recalls the practice of King John before Magna Carta. When he deprived a man of his lands the official record would record the reason as being "because we were cross with him.”

${ }^{7}$ The Evening Standard, May 122003. 


\section{THE DENNING LAW JOURNAL}

It could be said that none of this matters greatly so long as the judges, like Mr Justice Collins, are unaffected, as I am sure they are, in the job they do. But it is unpleasant all the same to be attacked, especially as judges, unlike the wicked animal in the proverb, do not defend themselves.

But there is a price to pay. For when Ministers criticise the judiciary as a whole, or attack the decisions of individual judges, it is inevitably taken up by the press. And people believe what they read. The Daily Telegraph reported the Prime Minister as saying that he was prepared for a "show down with the judiciary to stop the courts thwarting the Government's attempts to curb the record flow of asylum seekers into Britain.” He had ordered new legislation "to limit the role of judges in the interpretation of International Human Rights obligations and to reassert the primacy of Parliament." When the Prime Minister, if he was correctly reported, says that the judiciary are "thwarting the will of Parliament" in the matter of asylum seekers can anyone doubt that undermines the trust which people place in the judiciary? Fortunately, the polls all show that trust in the judiciary is still very high; far higher than trust in politicians. But trust is a precious commodity, and should not be put at risk.

Let me give an example of what I mean. Not long ago, I was startled to be told by a friend that he was much concerned about the attitude of judges in asylum cases. A few days later he sent me a leader from the Telegraph as confirmation of what he had been saying. The leader is headed "When judges stand in the way of justice." 8 The thrust of the article is that judges always and everywhere oppose repatriation orders not just of illegal immigrants but of known villains.

"Even if our judges were the wisest and the most disinterested people in Britain they would have no right to cross the line that separates the judiciary from the legislature.”

Our judges may not all be equally wise. But the suggestion in a responsible newspaper that they are not disinterested does enormous harm. And so does the suggestion that they continually cross the line that separates the judiciary from the legislature.

I go back to February 2003 when Mr Blunkett said he would have to "deal with the situation" as he put it. We did not have long to wait. On 27 November 2003, the Asylum and Immigration (Treatment of Claimants) Bill came on for its first reading in the House of Commons. By clause 10 there was to be a new Section 108A in the 2002 Act which would provide:

${ }^{8}$ The Daily Telegraph, September 242005. 


\title{
THE DENNING LAW JOURNAL
}

\begin{abstract}
"No court shall have any supervisory or other jurisdiction (whether statutory or inherent) in relation to the [Asylum and Immigration Appeal] Tribunal.”
\end{abstract}

There was no mistaking here the government's intention to change "the rules of the game." This was the showdown with the judges for which the Prime Minister had said he was prepared. The judges would no longer have the power to question decisions of the Tribunal. Errors of law would go uncorrected. The new clause 108A was heavily criticised by the Joint Committee on Human Rights in its 5th Report published on 10 February 2004. Ousting the review jurisdiction of the High Court would, in the view of the Joint Committee, be a direct challenge to the rule of law, which includes the principle that people should have access to the ordinary courts to test the legality of decisions of inferior tribunals. Such an ouster had not been justified by any argument advanced on behalf of the Government.

Despite the advice of the Human Rights Joint Committee the Home Secretary pressed ahead. When the Bill reached the House of Lords, the ouster clause was still there. But then a strange thing happened. Lord Irvine of Lairg put his name down to speak on second reading. Although he was often to be seen on Government back benches since his resignation as Lord Chancellor in June 2003, he had not opened his mouth. What he would have said on second reading we do not know. I would give much to have heard that speech. But as soon as he put his name down the ouster clause mysteriously disappeared from the Bill. And as soon as the ouster clause had disappeared from the Bill, Lord Irvine withdrew his name from the speakers list. I will always remember that incident as a paradigm example of power exercised from beyond the ministerial grave.

Pausing there, and returning to the title of my lecture, I hope I have shown that in the field of Judicial Review it is not the judges who have been seeking to "move the goalposts" but the executive. The attempt to exclude Judicial Review in asylum cases was, in my view, outrageous. Fortunately, it failed. I return later to speculate what would have happened if the attempt had succeeded. In the meantime, I remain puzzled why it was that neither the Lord Chancellor, nor other Ministers whose duty it is under the Constitutional Reform Act 2005 to uphold the existing rule of law and the continued independence of the judiciary, raised so much as an eyebrow. It makes me wonder how effective those solemn words will prove.

I now turn to the second of my two areas of tension. I start with another quotation. In 1996 a Conservative Government published its proposals for automatic life sentences for those convicted of a serious violent or sexual offence for the second time and minimum sentences of seven and three years 


\section{THE DENNING LAW JOURNAL}

for repeat class "A" drug offenders, and domestic burglars. In a speech in the House of Lords the Lord Chief Justice Lord Taylor said:

"I believe it to be of the first importance for me, while still holding the office of Lord Chief Justice, to inform the House directly of the grave consequences which will follow if the main proposals of the White Paper were given statutory affect . .. Quite simply, minimum sentences must involve a denial of justice.”

Those who heard that speech, as I did will never forget it. Lord Taylor was very ill. It required immense courage for him to come to the House at all. Within a month or two he had retired at Lord Chief Justice and within less than a year he had died.

The proposals which Lord Taylor has condemned were later implemented in the Crime (Sentences) Act 1997. When the Bill was going through Parliament, Lord Bingham of Cornhill, who had succeeded Lord Taylor as Lord Chief Justice, expressed his "profound anxiety." He posed four questions for consideration in the House of Lords. (1) Were the provisions just? (2) Would they protect the public by reducing the level of crime? (3) Would they be cost effective? (4) Would they be workable? He answered all four questions in the negative. I would give the same answer to all four questions today.

The Labour Government has added to the list of offences carrying a minimum sentence. Thus there is now a minimum sentence of five years for the possession of certain firearms. But more important the Government has introduced an elaborate scale of starting points for determining the minimum term to be served by a convicted murderer, together with detailed aggravating and mitigating factors to be taken into account. These powers are contained in the Criminal Justice Act 2003. They were Mr Blunkett's answer to the decision of the House in Lords in Anderson $v$ Secretary of State, ${ }^{9}$ the case in which it was held that the part hitherto played by the Home Secretary in fixing the so-called tariff for convicted murderers was contrary to Article 5 of the European Convention.

Why are minimum sentences so unjust? The reason is simple. The purpose of all good sentencing must be to make the punishment fit the particular crime not the criminal offence. The circumstances in which crimes are committed are infinitely various. This is above all true in the case of murder which ranges from mercy killing at one end of the spectrum to the most brutal and most sadistic murders at the other. But the same is also true of other

${ }^{9}$ [2003] 1 AC 837. 


\section{THE DENNING LAW JOURNAL}

crimes for which minimum sentences have been set. It is the function of the judge who presides at a criminal trial - perhaps his most important function - to determine the sentence. He has seen the defendant in the dock. He has heard all the evidence. He knows all the circumstances. He is aware of the defendants previous record. He will be familiar with the guidelines laid down from time-to-time by the Court of Appeal for similar offences. Why then can the judge not be trusted to impose the appropriate sentence? Why should Parliament want to place him in a sentencing straight-jacket?

It is said that Parliament must have a hand in sentencing so that it can reflect the views of the electorate. But this greatly under-estimates the extent to which sentencing policy is already influenced by public opinion. Let me give an example from my own experience. When I first became a judge most cases of causing death by dangerous driving were dealt with by a fine or short sentence of imprisonment. For the most serious cases it could be eighteen months or perhaps two years at the most. Nowadays such offences would meet with a sentence of six or eight years. That has been brought about not by Parliament imposing a minimum sentence, but by Parliament increasing the maximum sentence, from seven to fourteen years, a sure way of bringing about a rise in the general level of sentences for a particular offence, if that is what is required. But it has also been brought about by the judges' own understanding of what the public requires. It is said that that is a job for politicians, not judges. The judges are "out of touch with the real world." I am not so sure. Judges, like everybody else, read the newspapers and watch television. Like everyone else they learn from experience, from conducting trials and hearing appeals. A research project carried out among juries has shown that when jurymen have been asked whether they agreed or disagreed with the sentence of the judge, one third had no view one way or the other and can therefore be disregarded. But one third said that the sentence was just about right. Of the remaining third, half said the sentence was more than they expected and half said that it was less. Is it just possible that judges are more in touch with the real world than politicians imagine? More even, dare I say, than the politicians themselves? And by real world I mean the twelve men and women whom they see in the jury box every day?

Of course there will be cases where the sentence is much too low just as there are cases where the sentence is much too high. But that problem is not solved by a regime of minimum sentences. It is solved by the Court of Appeal. That is the very reason why the Attorney-General is given power to refer cases to the Court of Appeal if he is of the view that the sentence is unduly lenient. I have to confess that I was opposed to that reform at the time. But I have changed my mind. The reform has worked.

Then it is said that the discretion of the judge is not excluded altogether, since the judge is entitled to disregard the minimum sentence if in his opinion, 


\section{THE DENNING LAW JOURNAL}

which he must state in open court, there are exceptional circumstance. But "exceptional circumstances" are not defined; and in practice the term is given a narrow meaning. Although it will enable the judge to mitigate the harshness of a minimum sentence in some of the cases to which the minimum sentences would apply, in the great majority of cases, it will not.

Then it is said that minimum sentences have worked well enough in the United States. So they could be made to work here. But minimum sentences are not working well in the United States. They are a source of constant friction between the judges and Congress. In 1984 Congress passed the Sentencing Reform Act which laid out an elaborate sentencing framework within which federal judges are obliged to work. But it allowed what are called downward departures from the sentencing guidelines. The 1984 Act was passed after full consultation with the Judiciary. Not so the Protect Act which was passed by Congress in 2003. Members of Congress evidently believed that there were too many "downward departures from the sentencing guidelines." At least that was the explanation given by the late great Chief Justice Rehnquist in his 2003 year-end report on the Federal Judiciary. Under the provisions of the Protect Act, Congress will gather information about individual judges. They will discover how often and to what extent individual judges have sentenced below the guidelines. The Chief Justice described this in his report as "somewhat troubling." He was not given to overstatement. It could, he said, "appear to be an unwarranted and ill considered effort to intimidate individual judges in the performance of their judicial duties." It is clear both from his 2003 report and from his subsequent and last report in 2004 that Rehnquist CJ was seriously concerned by the effect that minimum sentences was having on relations between Congress and the judiciary. It is not an example which we should follow.

The experience of the United States shows also that where discretion is excluded in one area of the law it will always break out in another. This phenomenon was described by Lord Bingham in the speech from which I have already quoted. It was subsequently referred to by Earl Russell as "Bingham's Law." The consequence of Bingham's Law is that minimum sentences may well prove counter productive in practice. If a successful prosecution for a second serious offence would produce a result which is obviously unfair, one of two things will happen. Either the prosecution will proceed on a lesser offence, which does not attract the automatic life sentence; or if the prosecution proceeds with the more serious offence the jury will refuse to convict. Putting it at its lowest, a defendant faced with a second trial, is unlikely to plead guilty even if he is caught red-handed.

So why do governments place so much faith in minimum sentences? Their stated object is usually to protect the public. For that purpose they say they must send out a "clear message" that repeat offences will not be tolerated. But 


\section{THE DENNING LAW JOURNAL}

I sometimes wonder who actually receives these messages. Is there any evidence that these messages are ever received by the criminals themselves who may or may not be minded to commit a second serious offence? Is there any evidence that they are actually deterred? Is it unduly cynical to think that the real reason for introducing minimum sentences is the same as that which underlies so much Government legislation that the Government wants to be seen to be doing something about something, in this case rising crime. I remember so well after the Omagh bombing in 1994 Parliament was recalled. Tough new measures were promised. (Incidentally why do tough new measures always come in rafts?) But what emerged was a provision which enables a Police Officer of certain seniority to give evidence in court that in his opinion the defendant belonged to a terrorist organisation. Needless to say, that extraordinary provision which, to its shame, has now been re-enacted as Section 108 of the Terrorism Act $2000^{10}$ has never been of the slightest use to anyone. But it served its purpose of demonstrating that the Government was doing something.

Once again I return to my title. Have "the goalposts moved?" The answer must be "yes." And it is the legislature which has moved the goalposts by depriving the judges of their discretion in an important field of sentencing. Section $269^{11}$ and Schedule 21 of the Criminal Justice Act 2003 was an attempt by the legislature, successful in the event, to regain some of the ground lost by the Home Secretary as a result of the decision in Anderson's case. Some commentators referred to it as "Blunkett's revenge." But let the last words be with Lord Woolf. In a speech on second reading of the Bill in the House of Lords which was as wise as it was restrained, he drew attention to the vital importance of taking sentencing out of politics, particularly in the case of crimes as serious as murder. He was surely right. And may I point out in

10 Section 108:

[This section was amended by the Police (Northern Ireland) Act 2000, s 78(2).]

(1) This section applies where a person is charged with an offence under section 11.

(2) Subsection (3) applies where a police officer of at least the rank of superintendent states in oral evidence that in his opinion the accused-

(a) belongs to an organisation which is specified, or

(b) belonged to an organisation at a time when it was specified.

(3) Where this subsection applies-

(a) the statement shall be admissible as evidence of the matter stated, but

(b) the accused shall not be committed for trial, be found to have a case to answer or be convicted solely on the basis of the statement.

(4) In this section 'police officer' means a member of-

(a) a police force within the meaning of the Police Act 1996 or the Police (Scotland) Act 1967, or

(b) the Police Service of Northern Ireland."

${ }^{11}$ Determination of minimum term in relation to mandatory life sentence. 


\section{THE DENNING LAW JOURNAL}

passing, now that I have quoted from the speeches of three Chief Justices in the House of Lords, that we shall never again hear the voice of the Chief Justice in Parliament again when Part 6 of the Constitutional Reform Act is brought into force. This is something I deeply regret.

Anderson's case, to which I referred a moment or so ago, leads me naturally to the field of Human Rights. It was impossible in that case to read the relevant statutory provisions so as to give effect to Article 6 of the Convention, so Section 3 of the Human Rights Act was not available. The House of Lords had no alternative but to make a declaration of incompatibility under Section 4. Different views have been expressed as to whether Section 3 or Section 4 was intended to be the primary remedy under the Human Rights Act. Whatever the correct view about that, it is at least certain that Section 4 has proved effective. In the few years since the Act came into force there have been seventeen declarations of incompatibility, of which five were overturned on appeal. In every case where a declaration has been made, and not overturned, the Government has responded by repealing or amending the relevant legislation. The most recent and by far the most significant case was the Government's response to the Belmarsh decision. I shall come back to that case in a moment. But first I must return to my title.

Has the Human Rights Act moved the goal posts? The answer is obvious. Of course it has. But not perhaps to quite extent that most people imagine, and certainly not to the extent that some commentators would wish. The judges have always enforced human rights. What the Convention did was to spell out the rights in the form of code. From the moment the Convention came into force on 21 September 1953 our courts have interpreted ambiguous legislation so far as they could, in a way which was compatible with the Convention. This is something which the courts have always done. From the moment in January 1966 when the United Kingdom accepted the right of individual petition, there has been a succession of cases brought before the court in Strasbourg in which the United Kingdom has been found to have breached Convention rights. So the rights were there and could, if necessary, be enforced.

What was new about the Human Rights Act in 1998 was that it "brought rights home." I have often wondered who invented that description. It may have been Jack Straw himself, when he was Shadow Home Secretary. But whoever it was, it was a stroke of genius. The Act brought home rights in two quite different senses. It enabled "home grown” judges to do what was already being done by judges in Strasbourg. But it also brought home rights to the British people. The passing of the Human Rights Act did more than anything to raise awareness of human rights, and our ability to enforce those rights in a domestic court.

So the judges in England and Scotland have a new and important role. It is a role which they acquired from a Labour Government, after many years of 


\section{THE DENNING LAW JOURNAL}

resistance by the Conservatives. Indeed it is a role which is increasingly thrust on the judges in current legislation. The 2002 Nationality, Immigration and Asylum Act is a good example. Section 55(1) prohibits the Home Secretary from providing support to late applicants. But s 55(5) obliges him to provide support if is necessary to do so in order to avoid a breach of his human rights. This is the narrow path which the House of Lords explored in Limbuela's case.

The ground on which the Conservatives opposed incorporation of the Convention was that it would give too much power to the judges, and tempt them to cross the forbidden line into the realm of political decision making. While in one sense the judges have been given more power (although I would prefer to say they have been given a new role) they have been scrupulously careful not to cross the forbidden line. This was never more clearly shown than in the Belmarsh case.

The facts are now so well known, that a brief summary will suffice. Under Part 4 of the Anti-Terrorism Crime and Security Act 2001, the Government took power to detain foreign nationals who were suspected of being terrorists, if, for one reason or another, they could not be deported. Since detention without charge was the clearest possible breach of the right to liberty under Article 5 of the Convention, the United Kingdom was obliged to derogate from the Convention under Article 15. Accordingly, on 11 November 2001 the Home Secretary made a designated derogation order which was subsequently approved by Parliament on 21 November. Sixteen suspected terrorists were thereupon detained at Belmarsh under Part 4 of the Act.

Three years later, their case came before the House of Lords. The question was whether the derogation order was valid. This turned on whether there existed a public emergency threatening the life of the nation (the first issue), and, if so, whether the measures contained in Part 4 for the indefinite detention of foreign nationals without charge went beyond what was strictly necessary. Where those measures "strictly required by the exigencies of the situation."

On the first question eight out of nine Law Lords held that there were insufficient grounds to displace the decision of the Home Secretary that the safety of the nation was indeed threatened. But on the second question they held that the measures taken to deal with the threat went beyond what was strictly necessary. The reason for this view was that no such measures had been thought necessary in the case of British nationals. The evidence was that the threat posed by British nationals was as great as that posed by foreign nationals, a point of fact upon which the events of 7 July have proved the Law Lords to have been right. If the threat posed by British nationals could be contained by existing terrorist legislation without Part 4 of the 2001 Act, so could the threat from foreign nationals. Thus the Government's response to 9/11 was one which was not "strictly required by the exigencies of the situation.” Accordingly, they quashed the designated derogation order. But 


\section{THE DENNING LAW JOURNAL}

they could not, of course, quash Part 4 of the Act. They could only make a declaration of incompatibility, which they did.

The importance of the case for the future lies in the test that the Law Lords applied in answering the two questions. They rejected the Attorney-General's argument that the courts must defer to the executive in all cases involving national security. The best approach, according to Lord Bingham, was to analyse each issue according to its political content and its legal content. The greater the political content and the smaller the legal content, the less scope there would be for the judges to intervene. The first issue - whether there was a public emergency threatening the safety of the nation - lay at the political end of the spectrum. The issue was not one on which the Law Lords were well qualified to express a view as judges. Accordingly they declined to intervene.

On the second issue, whether the measures contained in Part 4 were a proportional response, the position was different. No doubt there was a political element in the decision, since it required the balancing of individual human rights against national security. But the decision was not purely political. It involved an element of judgment on which the Law Lords were qualified and entitled to express a view; and not only qualified and entitled, but obliged under the terms of the Human Rights Act. As Lord Brown of Eatonunder-Heywood has put it, "Judges nowadays have no alternative but to apply the Act. It is a responsibility which they cannot abdicate."

If the Government had rejected the decision in A's case, as it could have done, and renewed Part 4 of the 2001 Act when it expired, there would have been a major constitutional crisis. I shall never forget the sense of relief when on 21 January 2005 just a few days before Part 4 of the 2001 Act was due to expire, Mr Clarke as Home Secretary announced that the Government would accept the declaration of incompatibility. Part 4 of the 2001 Act would not be renewed. Instead it would be replaced by new legislation. Mr Clarke looked like a man in agony. But he made the right decision. I would like to think that Mr Clarke's quiet acceptance of the decision in A's case marked the start of a new chapter in the relationship between the judges and the executive. Instead of crying foul, as the Government might well have done when Mr Blunkett was Home Secretary, the executive has recognised that judges also have a job to do, especially in the realm of human rights. If this is so, then A's case was a decision of huge importance, not only in what it decided, but in the manner of the Government's acceptance of that decision.

Herein lies a paradox. The implementation of the Human Rights Act by the judges might have lead to even greater tension between the judges and the executive than has been the case in the field of Judicial Review and sentencing. In fact it has not, because of the care which judges have exercised not to cross the forbidden line. A's case was a shining example. If that example is followed by the judiciary, and if the executive shows the same self-restraint in 


\section{THE DENNING LAW JOURNAL}

other fields as Mr Clarke has shown in responding to A's case, then the omens are good.

I am glad to end on an upbeat note. But I have one short footnote to add.

I am alarmed by the Prime Minister's hint that he will introduce legislation to limit the role of judges in the interpretation of human rights obligations, and to reassert the primacy of Parliament. I hope he was misreported. Because he must know that it is for the judges, and ultimately for Strasbourg, to say what the Convention means. It has been said that Parliament can do anything except divide something into three equal fourths. But except in the land inhabited by Humpty Dumpty, even Parliament cannot make words mean what they do not mean. If the suggestion is that Parliament should change the words, then the question will arise whether we can remain parties to the Convention; and if we cease to be parties to the Convention the question will arise as to whether we can remain in Europe.

I am very conscious that I have not had time to touch on what many commentators and two or three distinguished members of the Court of Appeal see as the most important effect of the Human Rights Act, namely, that it marks the start of a move towards a new constitutional settlement, in which fundamental or constitutional rights will sit alongside the supremacy of Parliament, with sovereignty being shared between Parliament and the courts. It is an exciting thought. It requires another lecture, of which there have already been many. I would say only this. If we are to move in that direction, we must move with great caution. We cannot expect the executive to exercise selfrestraint in their dealings with the judges unless the judges do the same. This will at once class me, I know, among Lord Denning's timorous souls. But I must bear that with such equanimity as I can command. 